Egypt. Poult. Sci. Vol. (41) (III): (615-625) (2021)

http://www.epsj.journals.ekb.eg/

ISSN: 1110-5623 (Print) - 2090-0570 (Online)

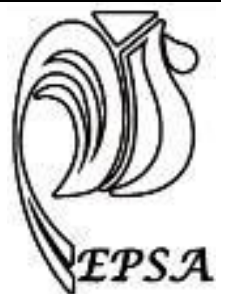

\title{
GROWTH RESPONSES TO SELECTION FOR HIGH BODY WEIGHT IN MEAT LINE OF JAPANESE QUAIL
}

\author{
A.A. A. Amrabit ${ }^{1}$, A.M. EI-Raffa ${ }^{2}$, A.E. El-dlebshany ${ }^{2}$ and A.S.A. Soliman ${ }^{2}$ \\ ${ }^{1}$ Plant Prod. Dep. (al-Kufrah), Fac. of Agric., Benghazi Uni., Libya. \\ ${ }^{2}$ Poult.Prod. Dep., Fac. of Agric., Alexandria Uni., Egypt.
}

Corresponding author: A.E. El-dlebshany. Email: amiraeldlebshany@yahoo.com

Received: $16 / 08 / 2021$

Accepted: $29 / 08 / 2021$

\begin{abstract}
The main objectives of the present study were to estimate the direct response to individual selection for high body weight at six weeks of age $\left(\mathrm{BW}_{6}\right)$ with estimated the realized heritability of $\mathrm{BW}_{6}$ from two successive selected generations of this line. Besides that, estimate the correlated responses for other growth traits in meat line of Japanese quail. The results were obtained from this work; the means of body weight at different ages for selected line were higher than for control line with highly significant differences in both selected generations. with respect to generation, the results were shown the heaviest body weight at all different ages in the second generation and the lightest in the base with highly significant differences. The results revealed improving of daily weight gain during different periods for selected line in both selected generations compared control line with significant differences. Among generations, the daily weight gains during all different periods of second selected generation were the highest than the rest of generations with highly significant differences. Direct selection response of $\mathrm{BW}_{6}$ was in the first generation $(16.76 \mathrm{~g})$. However, selection response decreases in the second generation $(5.97 \mathrm{~g})$. Finally of two selected generations, the body weight at 6 weeks of age increased by $22.73 \mathrm{~g}$. for selected line comparing with control line. Also, the selection for $\mathrm{BW}_{6}$ had positive correlated responses on body weight at hatch, 2 and 4 weeks of ages. The daily weight gains have improved after two generations of $\mathrm{BW}_{6}$ selection by $0.41,0.67,0.50$ and $0.53 \mathrm{~g} / \mathrm{d}$ during 0 (hatch) $-2,2-4,4-6$ and $0-6$ weeks of ages, respectively. It can conclude that the results of selection for high body weight at 6 weeks of age was caused improvement body weight at the same age and also improvements both of body weight at different ages and daily weight gain during different periods of quail growth stage. Moreover, these improvements were higher in the first generation of selection than the second.
\end{abstract}

Key words: Selection, Growth traits, Direct and correlated response, Quails 


\section{INTRODUCTION}

Recently, Japanese quails (Coturnix Coturnix Japonica) have been recommended as a good alternative source of animal protein. Quail strains of meat and/or eggs have become increasingly popular all over the world. In comparison with many sources of animal protein, Japanese quail has many desirable traits such as fast growth, early sexual maturity, high egg production and short generation interval therefore it showed quick response to selection (Alkan et al., 2010). On the other hand, characterizes of population are differing from farm to others and these trait are deteriorated rapidly. Growth can be improved by improving environmental influences such as diet, housing and management which differ by choosing the suitable mating system, sex ratio and parental age (Parks, 1971). While, for improving its genotypic value were by selection and/or by crossing.

Body weight at 6 weeks of age is considered as a marking age of meat quails, also it is the age to begin laying eggs (Yalcin et al., 1995). Body weight at marketing age and egg production are considered the most important economic traits of Japanese quail which are influenced by a complex genetic structure and environmental factors (Narinc et al., 2013 ). Moreover, the majority of the selection studies on quail have been conducted on meat production (Shahin et al., 2000, Abdel Fattah,2006, Hussen et al.,2016 and El-Attrouny et al., 2020).

In selection studies, the value of selection response influenced by the genetic correlation between selection criterion and other traits ,the heritability of tested traits and either sign or strength of the genetic covariance among them (Jensen et al., 2003). Positive genetic correlations among body weight at 42 days of age and other body weights at different ages were found (Abdel Fattah, 2006).

Several selection experiments indicated that the correlated response for unselected characteristics showed a positive correlation for increasing all body weight at different ages (El-Attrouny et al., 2020) and body weight gain during different periods (Ayatollahi Mehrgardi, 2013, Varkoohi and Kaviani, 2014, Hussen et al., 2016 and El-Attrouny et al., 2020).

The main objectives of the present study were to estimate the direct response of selection for high body weight at 6 weeks of age with estimate the realized heritability of body weight at 6 weeks of age for this line from the selected experiment. Besides that, estimate the correlated responses for other growth traits in meat line of Japanese quail.

\section{MATERIALS AND METHODS}

This study was conducted at the Poultry Production Department, Faculty of Agriculture, Alexandria University which selected quails for high body weight at 6 weeks of age during two successive generations. Finally, direct and correlated responses for the growth performance in this meat line of Japanese quail were estimated.

\section{Selection Program}

Throughout a selection experiment, a total of 2855 quails as a base population were obtained from this random mating which pedigree and weighted individual biweekly from one-day to 6-week of age, then divided into two groups $(75 \%$ of selected line and $25 \%$ of control line). Individual (phenotypic) selected for 140 sirs and 280 dams of selected line (SL) by high body weight at 6 -week of age $\left(\mathrm{BW}_{6}\right)$ 
Selection, Growth traits, Direct and correlated response, Quails

as a criterion of two successive generation, while the control line (CL) was kept under random mating without selection for two successive generations.

Studied Traits

The following growth traits were recorded:

1. Body weight (BW) at different ages: Body weights for each bird in grams at 0 (hatch), 2, 4 and 6 weeks of ages were recorded.

\section{Daily weight gain (DWG) during different period:}

Daily weight gain through the periods from hatch to 2 (0-2), 2- 4, 4- 6 and 0-6 weeks of age were calculated as follows:

Daily weight gain $=\left(\mathrm{W}_{2}-\mathrm{W}_{1}\right) /$ period

Where:

$\mathrm{W}_{1}=$ weight at the beginning of the period.

$\mathrm{W}_{2}=$ weight at the end of the period.

Statistical analysis:

Data of BW at different ages, daily weight gains during different periods were analyzed using (SAS,1992) for statistical analysis program, all percentage data were transformed to their corresponding arcsine angles according to Sndecor and Cochran (1981) before analysis. The significant tests for the differences between each two means for any studied trait were done according to Duncan (1955). Two different statistical models were used as follows:

$Y_{i j k}=\mu+G_{i}+L_{j}+G_{i} X L_{j}+e_{i j k}$

Where:

$\mathrm{Y}_{\mathrm{ijk}}$ : is the observation on the $l^{\text {th }}$ individual,

$\mu$ : is the overall mean,

$G_{i}$ : is the fixed effect of the generation,

$\mathrm{L}_{\mathrm{j}}$ : is the fixed effect of the line,

$\mathrm{G}_{\mathrm{i}} \times \mathrm{L}_{\mathrm{j}}$ : the effect of interaction of the $\mathrm{i}^{\text {th }}$ generation with the $\mathrm{j}^{\text {th }}$ line

$\mathrm{e}_{\mathrm{ijk}}$ : is the random error

\section{Selection parameters:}

Selection parameters for direct selection and correlated responses were measured in the present study for the two selected generation as following (Falconer, 1989).

\section{Selection differential (SD):}

The magnitude of the selection differential depends on two factors, the proportion of the population included among the selected group and the phenotypic standard deviation of the character. Selection differential at two selection generations was obtained according to Falconer (1989) as follows: $\mathrm{SD}=\mathrm{X}_{\mathrm{p}}-\mathrm{X}_{0}$

Where, $X_{p}$ : the selected parents` mean , and $\mathrm{X}_{0}$ : the population mean.

2. Selection intensity ( i ):

Selection intensity in standard units through different generations of selection was calculated according to Falconer (1989) as follows:

$\mathrm{i}=\mathrm{SD} / \delta_{\mathrm{p}}$

Where, SD : the selection differential, and $\delta_{\mathrm{p}}$ : the phenotypic standard deviation of the trait.

\section{Selection response $(R)$ :}

The actual response of selection for high body weight at 6 wks of age and correlated responses for other studies traits which we did not selected for them from generation to generation was estimated according to Guill and Washburn (1974) as follows.

$\mathrm{R}=$ (Means of selected progeny - Means of previous selected population) - (Means of control progeny - Means of previous control population)

\section{Realized heritability $\left(h^{2}\right)$ :}

The realized heritability $\left(h_{r}^{2}\right)$ was estimated from selected experimental according to Falconer (1989) as follows: $\mathrm{h}_{\mathrm{r}}^{2}=\mathrm{R} / \mathrm{SD}$

where, R: actual response of selection, and 
A.A. A. Amrabit et al.

SD: the selection differential of previous generation.

\section{RESULTS AND DISCUSSION} Body weight at different ages (BW):

Least squares means and standard errors for body weight at hatch, 2, 4, and 6 wks of ages for control and selected lines of Japanese quail during base and two generations of selection for BW6 are presented in Table (1). The means of body weight at different ages for selected line were higher than control line with highly significant differences in both selected generations. In first generation the different between selected line and control line were $0.83,5.59,11.41$ and $16.76 \mathrm{~g}$. for $\mathrm{BW}_{0}, \mathrm{BW}_{2}, \mathrm{BW}_{4}$ and $\mathrm{BW}_{6}$, respectively. The corresponding values in second generation were $0.54,6.36,15.69$ and 22.73 , respectively.

Similarly, selected lines in the literature for BW at different ages had significantly heavier BW's than the CL (Khaldari et al., 2010, Abou Khadiga et al. , 2014 , Taskin et al., 2017 and El-Attrouny et al., 2020). These differences increased in second selected generation for all body weight expect body weight at hatch.

In respect of generation, the results shown the heaviest body weight at all different ages in the second generation and the lightest in the base with highly significant differences. These results may be caused by environmental and management improvements. Similarly there were significant differences due to generation effect for BW's days (Emam, 2015 , Meabed, 2015 and Semida et al., 2019).

\section{Daily weight gain during different periods:}

Least squares means and standard errors for daily weight gain during hatch (0) - 2, $2-4,4-6$ and $0-6$ wks of ages for control and selected lines of Japanese quail during base and two generations of selection for $\mathrm{BW}_{6}$ are presented in Table (2). These results are shown improving of daily weight gain during different periods for selected line in both selected generations compare by control line with significant differences. These improvements may be due to selection process for BW6.

Generally among generations, the daily weight gains during all different periods of second selected generation were the highest than the rest of generations with highly significant differences. Also, the daily weight gains during different periods of first generation were higher than the base generation. These previous results may be due to improve of environmental and management conditions for flocks which were accompanying with improvement of selected line from generation to another. In agreement with the current findings, El-Attrouny et al., (2020) reported that generalized least squares estimates of the selection for the four generations were superior $(\mathrm{P}<0.05)$ for most $\mathrm{BW}$ and BWG comparing with the base population.

Selection body weight at 6 weeks of age:

Least square means for body weight at 6 weeks of age $\left(\mathrm{BW}_{6}\right)$ of control and selected lines and some parameters of selection during base and two generations of selection are presented and calculated in Table (3). The selected parents were 263.7 and $292.7 \mathrm{~g}$. for base and first generation, respectively which choice from selected line. The high selection differential $(37.12 \mathrm{~g})$ calculated in the base generation allow to increase selection response in the first generation $(16.76 \mathrm{~g})$. In the next generation, selection differential was $28.63 \mathrm{~g}$ (lower 
Selection, Growth traits, Direct and correlated response, Quails

than SD of base generation), so the response to selection in the second generation was decreased $(5.97 \mathrm{~g})$. These results were proving by increase selection intensity of base generation (1.25 units) that of the first generation (0.83 units). The cumulative response of the two selected generations was $22.73 \mathrm{~g}$. according to Guill and Washburn (1974). From these results, we can estimate the realized heritability which found 0.45 and 0.21 for first and second selected generation. These previous findings indicated that high actual genetic gain of the first selected generation and then decreased in the second selected generation which reflected at high $\mathrm{h}_{\mathrm{r}}^{2}$ estimate $(0.45)$ of $\mathrm{BW}_{6}$ at first generation and moderate $h_{r}^{2}$ estimate $(0.21)$ at next generation. These results may be due to decrease the genetic variance from $\mathrm{G}_{1}$ to $\mathrm{G}_{2}$ which expected in selection experimental. These results agreed with Marks, 1975 in quails who found that the rapid genetic improvement was occurred during the early generations, however in later ones, improving appeared to be diminished. These results found in the quails more than in the other avian species. $h^{2}$ estimates of $\mathrm{BW}$ were increased with the advancement of age of Japanese quail (Saatci et al. ,2003, Nasiri Foomani et al. ,2014, and Karami et al. ,2017),Conversely, $\mathrm{h}^{2}$ for $\mathrm{BW}_{6}$ was moderate $(0.22)$ as reported by ElAttrouny et al., (2020).

This increased direct selection response in the selected generations showed the efficiency of selection for BW at 6 weeks of age. The estimation of selection responses were necessary for the assessment of the breeding programs. The results in this work, were disagreed with those of Hussain et al., (2014) and El-Attrouny et al.,(2020), who found a linear increasing trend of selection criterion in selected populations as the generations advanced.

Correlated growth responses to selection for body weight at 6 weeks of age:

The correlated responses for body weight at 0 (hatch), 2 and 4 weeks of ages at first and second generations and the cumulative of both generations of selection for $\mathrm{BW}_{6}$ were calculated in Table (4). There is a positive impact on body weight at different ages of each generation expect $\mathrm{BW}_{0}$ at the second generation due to selection for $\mathrm{BW}_{6}$. The increases of body weight in first selection were higher than the second generation for all studied ages. Generally, there are increased in body weight at $0,2,4$ weeks of ages by $0.54,6.36$ and $15.69 \mathrm{~g}$., respectively after two generations of selection for BW6 These results indicated that the selection for $\mathrm{BW}_{6}$ had positive responses on body weight at hatch, 2 and 4 weeks of ages. The present results of the studied correlated estimates for BW and BWG traits were in the range of reviewed studies (Abdel Fattah, 2006, Ayatollahi Mehrgardi, 2013; Varkoohi and Kaviani, 2014; Hussen et al., 2016 and El-Attrouny et al., 2020).

The correlated responses for daily weight gain during 0 (hatch) - 2, 2-4, 4 - 6 and $0-6$ weeks of ages at first and second generations and the cumulative of both generations of selection for $\mathrm{BW}_{6}$ were calculated in Table (5). The same trends of body weight at different age were found in daily weight gain during different periods at both selected generations. So, we found that the improvements of daily weight gain during different periods at first generation were higher than the second generation of selection. Generally, the daily weight 


\section{A.A. A. Amrabit et al.}

gains were improved after selection of two generations by $0.41,0.67,0.50$ and $0.53 \mathrm{~g} / \mathrm{d}$ during 0 (hatch) $-2,2-4,4-6$ and $0-6$ weeks of ages, respectively. A similar trend was observed for the magnitude of correlated responses to selection for body weights at different ages and body weight gain during different periods decreased with the advance of generations (Ayatollahi Mehrgardi, 2013, Varkoohi and Kaviani,
2014, Hussen et al., 2016 and ElAttrouny et al., 2020).

It can conculcated that the results of selection for body weight at 6 weeks of age had positive responses on body weight at different ages and daily weight gain during different periods of quail growth period. Moreover, these improvements were higher in the first generation of selection than the second one.

Table (1) : Least Squares Means \pm SE for body weight (g) at 0 (hatch), 2, 4 and 6 weeks of age for selected and control lines of experimental generations.

\begin{tabular}{|c|c|c|c|c|}
\hline \multirow{2}{*}{ S. O. V } & \multicolumn{4}{|c|}{$\mathbf{L S M} \pm \mathbf{S E}$} \\
\hline & BW0 & BW2 & BW4 & BW6 \\
\hline Base & $8.96 \pm 0.05$ & $50.86 \pm 0.62$ & $161.04 \pm 1.05$ & $226.58 \pm 1.45$ \\
\hline \multicolumn{5}{|l|}{ Line } \\
\hline $\mathrm{CL}_{1}$ & $8.41^{b} \pm 0.26$ & $65.61^{\mathrm{b}} \pm 3.13$ & $170.71^{b} \pm 5.64$ & $247.31^{b} \pm 7.23$ \\
\hline $\mathrm{SL}_{1}$ & $9.24^{\mathrm{a}} \pm 0.25$ & $71.20^{\mathrm{a}} \pm 3.12$ & $182.12^{\mathrm{a}} \pm 5.60$ & $264.07^{\mathrm{a}} \pm 7.18$ \\
\hline Difference : & 0.83 & 5.59 & 11.41 & 16.76 \\
\hline $\begin{array}{l}\text { Level of } \\
\text { significance }\end{array}$ & $* * *$ & $* * *$ & $* * *$ & $* * *$ \\
\hline \multicolumn{5}{|l|}{ Line } \\
\hline$\overline{\mathrm{CL}_{2}}$ & $9.05^{b} \pm 0.07$ & $75.53^{b} \pm 0.74$ & $181.25^{b} \pm 1.27$ & $247.12^{b} \pm 1.69$ \\
\hline $\mathrm{SL}_{2}$ & $9.59^{a} \pm 0.05$ & $81.89^{a} \pm 0.49$ & $196.94^{\mathrm{a}} \pm 0.84$ & $269.85^{\mathrm{a}} \pm 1.11$ \\
\hline Difference : & 0.54 & 6.36 & 15.69 & 22.73 \\
\hline $\begin{array}{l}\text { Level of } \\
\text { significance }\end{array}$ & $* * *$ & $* * *$ & $* * *$ & $* * *$ \\
\hline \multicolumn{5}{|l|}{ Generation } \\
\hline Base & $8.96^{c} \pm 0.05$ & $50.86^{c} \pm 0.62$ & $161.04^{c} \pm 1.05$ & $226.58^{c} \pm 1.45$ \\
\hline $\mathrm{G}_{1}$ & $9.15^{b} \pm 0.05$ & $70.94^{b} \pm 0.59$ & $177.20^{b} \pm 1.00$ & $255.09^{b} \pm 1.38$ \\
\hline $\mathrm{G}_{2}$ & $9.59^{\mathrm{a}} \pm 0.04$ & $81.67^{\mathrm{a}} \pm 0.54$ & $197.24^{\mathrm{a}} \pm 0.92$ & $270.56^{\mathrm{a}} \pm 1.27$ \\
\hline $\begin{array}{l}\text { Level of } \\
\text { significance }\end{array}$ & $* * *$ & $* * *$ & $* * *$ & $* * *$ \\
\hline GxL & $* * *$ & $* * *$ & $* * *$ & $* * *$ \\
\hline
\end{tabular}

CL : Control line, SL: selected line for high body weight at 6 weeks of age,

$\mathrm{BW}_{0}, \mathrm{BW}_{2}, \mathrm{BW}_{4}$ and $\mathrm{BW}_{6}$ : Body weights at hatch, 2, 4 and 6 weeks of ages,

GxL: Interaction significance between generation and line, $* * *$ : significance at 0.001 
Table (2) : Least Squares Means \pm SE for daily weight gain ( g/d ) during different periods for selected and control lines of experimental generations:

\begin{tabular}{|c|c|c|c|c|}
\hline \multirow{2}{*}{ S. O. V } & \multicolumn{4}{|c|}{$\mathbf{L S M} \pm \mathbf{S E}$} \\
\hline & DWG 02 & DWG 24 & DWG 46 & DWG 06 \\
\hline Base & $2.99 \pm 0.04$ & $7.87 \pm 0.06$ & $4.68 \pm 0.10$ & $5.18 \pm 0.03$ \\
\hline \multicolumn{5}{|l|}{ Line } \\
\hline$\overline{C L_{1}}$ & $4.09^{b} \pm 0.22$ & $7.51^{b} \pm 0.30$ & $5.47^{b} \pm 0.49$ & $5.69^{b} \pm 0.17$ \\
\hline $\mathrm{SL}_{1}$ & $4.43^{a} \pm 0.22$ & $7.92^{a} \pm 0.30$ & $5.85^{\mathrm{a}} \pm 0.48$ & $6.07^{\mathrm{a}} \pm 0.17$ \\
\hline $\begin{array}{c}\text { Level of } \\
\text { significance }\end{array}$ & $* * *$ & $* * *$ & $* *$ & $* * *$ \\
\hline \multicolumn{5}{|l|}{ Line } \\
\hline $\mathrm{CL}_{2}$ & $4.75^{b} \pm 0.05$ & $7.55^{b} \pm 0.06$ & $4.71^{b} \pm 0.09$ & $5.67^{b} \pm 0.04$ \\
\hline $\mathrm{SL}_{2}$ & $5.16^{\mathrm{a}} \pm 0.03$ & $8.22^{a} \pm 0.04$ & $5.21^{\mathrm{a}} \pm 0.06$ & $6.20^{\mathrm{a}} \pm 0.03$ \\
\hline $\begin{array}{c}\text { Level of } \\
\text { significance }\end{array}$ & $* * *$ & $* * *$ & $* * *$ & $* * *$ \\
\hline \multicolumn{5}{|l|}{ Generation } \\
\hline Base & $2.99^{c} \pm 0.04$ & $7.87^{b} \pm 0.06$ & $4.68^{c} \pm 0.10$ & $5.18^{c} \pm 0.03$ \\
\hline $\mathrm{G}_{1}$ & $4.41^{b} \pm 0.04$ & $7.59^{c} \pm 0.06$ & $5.56^{\mathrm{a}} \pm 0.09$ & $5.86^{b} \pm 0.03$ \\
\hline $\mathrm{G}_{2}$ & $5.15^{\mathrm{a}} \pm 0.04$ & $8.26^{a} \pm 0.05$ & $5.24^{b} \pm 0.09$ & $6.21^{a} \pm 0.03$ \\
\hline $\begin{array}{c}\text { Level of } \\
\text { significance }\end{array}$ & $* * *$ & $* * *$ & $* * *$ & $* * *$ \\
\hline GxL & $* * *$ & $* * *$ & $* * *$ & $* * *$ \\
\hline
\end{tabular}

CL : Control line, SL: selected line for high body weight at 6 weeks of age, DWG 02, DWG 24, DWG 46 and DWG 06: Daily weight gain through the periods from hatch to 2 (0-2), 2-4 , 4-6 and 0-6 weeks of age, GxL: Interaction significance between generation and line, $* *$ and ${ }^{* * *}$ : significance at 0.01 and 0.001 , respectively.

Table (3): Least square means for body weight at 6 weeks of age of control and selected lines, selection differential, selection intensity, direct selection response and realized heritability of selection experimental.

\begin{tabular}{|l|c|c|c|c|c|c|c|}
\hline Generations & $\begin{array}{l}\text { Control } \\
\text { line }\end{array}$ & $\begin{array}{l}\text { Selected } \\
\text { line }\end{array}$ & $\begin{array}{l}\text { Selected } \\
\text { parents }\end{array}$ & $\begin{array}{l}\text { Selection } \\
\text { differential }\end{array}$ & $\begin{array}{l}\text { Selection } \\
\text { intensity }\end{array}$ & $\begin{array}{l}\text { Selection } \\
\text { response }\end{array}$ & $\begin{array}{l}\text { Realized } \\
\text { heritability }\end{array}$ \\
\hline Base & 226.58 & 226.58 & 263.7 & 37.12 & 1.25 & - & - \\
$\mathrm{G}_{1}$ & 247.31 & 264.07 & 292.7 & 28.63 & 0.83 & 16.76 & 0.45 \\
$\mathrm{G}_{2}$ & 247.12 & 269.85 & - & - & - & 5.97 & 0.21 \\
Cumulative & & & & 65.75 & - & 22.73 & 0.35 \\
\hline
\end{tabular}


Table (4) : Correlated and cumulative responses for body weight (g) at different ages of experimental generations.

\begin{tabular}{|c|c|c|c|}
\hline Traits & Generations & $\begin{array}{l}\text { Correlated responses } \\
\text { (g) }\end{array}$ & $\begin{array}{l}\text { Cumulative responses } \\
\text { (g) }\end{array}$ \\
\hline BW0 & $\begin{array}{l}\text { G1 } \\
\text { G2 }\end{array}$ & $\begin{array}{c}0.83 \\
-0.29\end{array}$ & 0.54 \\
\hline BW2 & $\begin{array}{l}\text { G1 } \\
\text { G2 }\end{array}$ & $\begin{array}{l}5.59 \\
0.77\end{array}$ & 6.36 \\
\hline BW4 & $\begin{array}{l}\text { G1 } \\
\text { G2 } \\
\end{array}$ & $\begin{array}{c}11.41 \\
4.28 \\
\end{array}$ & 15.69 \\
\hline
\end{tabular}

$\mathrm{BW}_{0}, \mathrm{BW}_{2}$ and $\mathrm{BW}_{4}$ : Body weights at hatch, 2 and 4 weeks of ages.

Table (5): Correlated and cumulative responses for daily weight gain (g/d) during different periods of experimental generations.

\begin{tabular}{|l|c|c|c|}
\hline Traits & Generations & $\begin{array}{l}\text { Correlated } \\
\text { responses (g/d) }\end{array}$ & $\begin{array}{l}\text { Cumulative } \\
\text { responses (g/d) }\end{array}$ \\
\hline DWG 02 & G1 & 0.34 & 0.41 \\
& G2 & 0.07 & 0.67 \\
\hline DWG 24 & G1 & 0.41 & 0.50 \\
& G2 & 0.26 & 0.53 \\
\hline DWG 46 & G1 & 0.38 & \\
\hline DWG 06 & G2 & 0.12 & 0.38 \\
& G2 & 0.15 & \\
\hline
\end{tabular}

DWG 02, DWG 24, DWG 46 and DWG 06: Daily weight gain through the periods from hatch to 2 (0-2), 2-4 , 4-6 and 0-6 weeks of age, 
Selection, Growth traits, Direct and correlated response, Quails

\section{REFFERENCES}

Abdel Fattah, M. H. 2006. Selection for increased body weight and growth rate in Japanese quail. Ph. D. Thesis, Fac. Agric., Fayoum Univ., Egypt.

Abou Khadiga' G., B. Y. F. Mahmoud and E. A. El-Full 2014. Genetic evaluation of a crossbreeding experiment included two selected lines of Japanese quail and their crosses for some growth and maturity-related traits. Egypt. Poult. Sci. 34: 831-848.

Alkan, S., Karabağ, K., Galiç, A., Karslı, T. and Balcığlu, M.S2010.Determination of bodyweight and some carcass traits in Japanese quails (Coturnix coturnix japonica) of different lines. Kafkas Univ. Vet. Fak. Derg. 16:277-280. DOI: $10.9775 / \mathrm{kvfd} .2009 .687$.

Ayatollahi Mehrgardi, A., 2013. Divergent selection for four-week bodyweight in Japanese quail (Coturnix coturnix japonica): Response to selection and realized heritability. J. Livest. Sci. Technol. 1, 57-59.

Duncan, D.B. 1955. Multiple range and multiple F tests. Biometrics. 11: 1-42.

El-Attrouny, M. M., E. A. Manaa, and S. I. Ramadan 2020. Genetic evaluation and selection correlated response of growth traits in Japanese quail. South African Journal of Animal Science, 50 (2): 325-333.

Emam, A. M. 2015. Selection for high body weight under two nutritional environments in Japanese quail. Ph. D. Thesis, Fac. Agric., Fay. Univ., Egypt.

Falconer, D. S., 1989. Introduction to Quantitative Genetics, Ed. 3. Longmans Green/John Wiley \& Sons, Harlow, Essex, UK/New York.

Guill, R. A. and K. W. Washburn 1974. Genetic changes in efficiency of feed utilization of chickens maintaining body weight constant. Poult. Sci., 53:1146-1154.

Hussain, J., Akram, M., Sahota, A.W., Javed, K., Ahmad, H.A., Mehmood, S., Jatoi, A.S. \& Ahmad, S., 2014. Selection for higher three-week bodyweight in Japanese quail: 2 . Estimation of genetic parameters. J. Anim. Plant. Sci. 24, 869-873.

Hussen, S. H., A. M., Abdulrahman AlKhdri, and A. M. Hassan 2016. Response to selection for body weight in Japanese Quail (Coturnix coturnix japonica). Iranian Journal of Applied Animal Science., 6 (2): 453-459.

Jensen, H., B. E. Saether, T. H. Ringsby, J. Tufto, S. C. Griffith and H. Ellegren. 2003. Sexual variation in heritability and genetic correlations of morphological traits in house sparrow (Passer domesticus). J. Evol. Biol. 16:1296-1307.

Karami, K., Zerehdaran, S., Tahmoorespur, M., Barzanooni, B. \& Lotfi, E., 2017. Genetic evaluation of weekly bodyweight in Japanese quail using random regression models. Br. Poult. Sci. 58,13-18. https://doi.org/10.1080/00071668.2016 .1236362 .

Khaldari , M., A. Pakdel, H. M. Yegane, A. N. Javaremi and $P$. Berg 2010. Response to selection and genetic parameters of body and carcass weights in Japanese quail selected for 4-week body weight. Poult. Sci., 89 :1834-1841.

Marks, H. L. 1975. Relationship of embryonic development to egg weight, hatch weight and growth in Japanese quail. Poult. Sci., 54:257- 1262.

Meabed, S.A.A. 2015. Response to three generation of divergent selection for 
A.A. A. Amrabit et al.

shank length in Japanese quail. Ph. D. Thesis, Fac. Agric., Fay. Univ., Egypt.

Narinc, Dogan Emre Karaman , Tulin Aksoy, and Mehmet Ziya Firat 2013. Genetic parameter estimates of growth curve and reproduction traits in Japanese quail. Poultry Science 93 :24-30.

Nasiri Foomani, N., Zerehdaran, S., Ahani Azari, M. \& Lotfi, E., 2014. Genetic parameters for feed efficiency and bodyweight traits in Japanese quail. Br. Poult. Sci. 55, 298-304. https://doi.org/10.1080/00071668.2014 .925088.

Parks, J.1971.Phenomenology of animal growth. N. C. State Univ. Raleigh.

Saatci, M., Ap Dewi, I. \& Aksoy, A.R., 2003. Application of REML procedure to estimate the genetic parameters of weekly live weights in one to one sire and dam pedigree recorded Japanese quail. J. Anim. Breed. Genet. 120, 23 28. https://doi.org/10.1046/j.14390388.2003.00370.

SAS Institute. 1992.SAS_ User's Guide: Statistics. SAS Institute Inc., Cary, NC,USA.

Semida, D.A.M.,B.Y.F., Mahmoud,E. A. El-Full and A. M. Emam 2019. Effects of selection for increasing early growth rate on growth and carcass characteristics of Japanese quail. Egypt. Poult. Sci. Vol. (40) (I): $1-14$.

Shahin, K. A.,A. R. Shemeis,O.Y. AbdAllah and K.. Saleh 2000. Selection index alternatives for increased marketing body weight with minimum concomitant reduction in body bone percentage- recourse to tissue dissection on Japanese quail. Arch. Tierz., Dummerstorf 43 : 5, 535-543.

Snedecor, G. W. and W.G. Cochran 1981. Statistical Methods 7th Iowa State Univ. Press Ames, Iowa, USA.

Taskin A. , U. Karadavut , R. I. Tunca, S. Genc and H. Cayan 2017. Effect of selection for body weight in Japanese quails (Coturnix coturnix Japonica) on some production traits. Indian J. Anim. Res., 51:358-364.

Varkoohi, S. and Kaviani, K., 2014. Genetic improvement for bodyweight of Japanese quail. Annu. Res. Rev. Biol.

347-353. https://doi.org/10.9734/ARRB/2014/5 281.

Yalcin, S., I. Ogus and S. Otles. 1995. Carcass characteristics of quail (Cortunix cortunix Japonica) slaughtered at different ages. British Poultry Sci., 36: 393-399. 
Selection, Growth traits, Direct and correlated response, Quails

$$
\begin{aligned}
& \text { الملخص العربيى } \\
& \text { استجابات النمو للإنتخاب لوزن الجسم العالى فيى خط لحم من السمان اليابانى }
\end{aligned}
$$

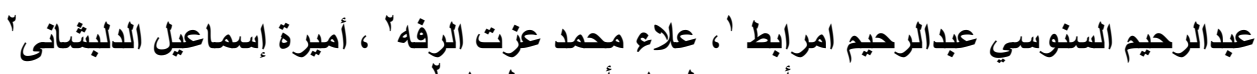

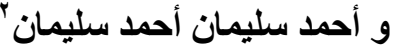

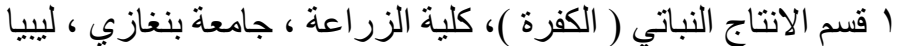

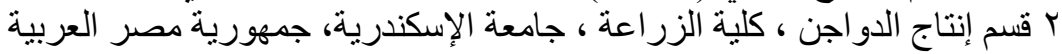

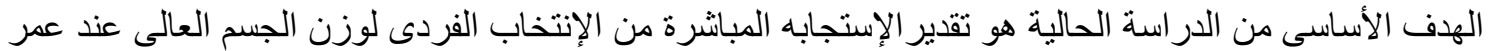

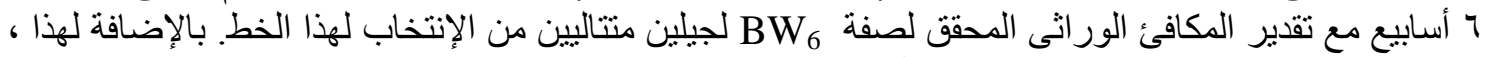

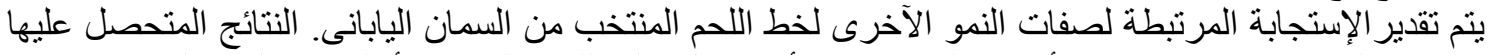

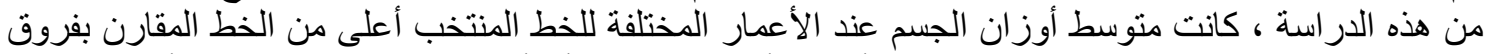

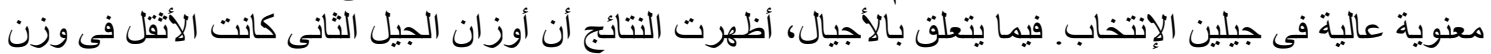

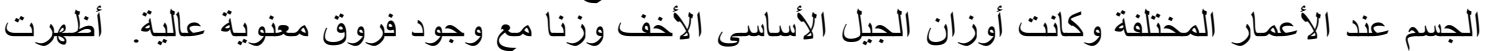

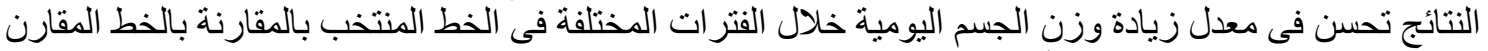

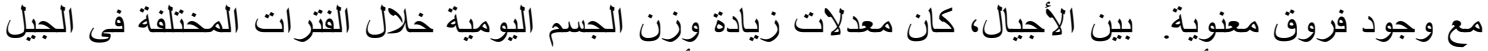

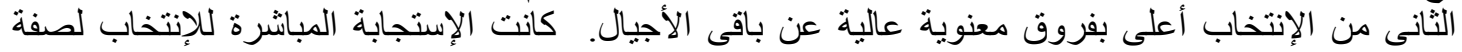

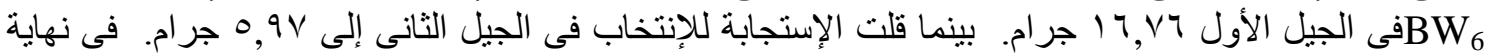

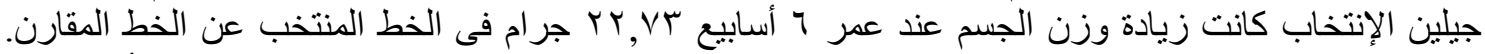
ايضا كان الإنتخاب لصفة

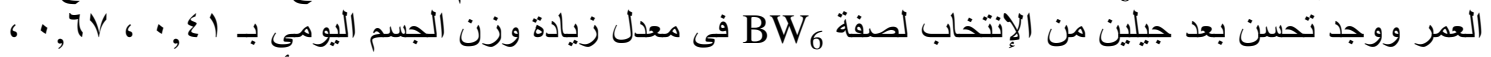

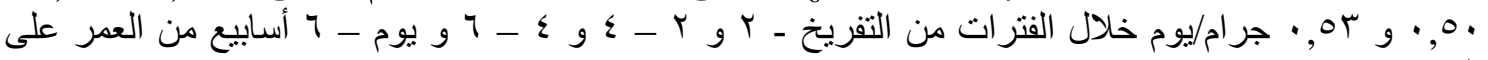
الترتيب.

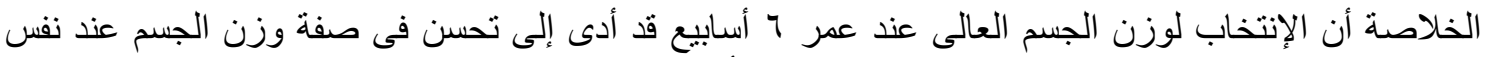

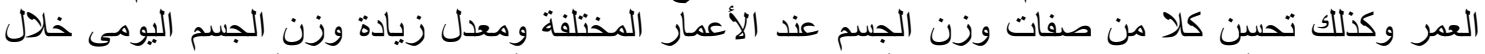

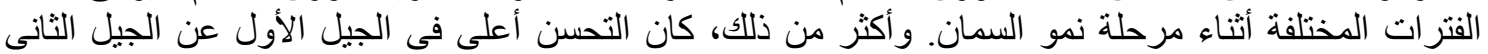

